\title{
İnsan Onuru ve Rencide Paradoksu ${ }^{1}$
}

\section{Ralf Stoecker}

\section{(Çeviren: Büşra Çakıl)}

\begin{abstract}
“Hiçbir siperin engel olamayacağı ve hiçbir elin karşı koyamayacağ1 polis yumruğunun ilk darbesiyle hayatımızın bir kısmı sona ermişti ve hiçbir zaman yeniden diriltilemez" (Jean Améry, Jenseits von Schuld und Sühne, Stuttgart 1977, s. 77).
\end{abstract}

“Dozu ayarlanmış elektroşoklar kişiliğin değerini hiçbir şekilde azaltmazlar" (General Jacques Massu, Fransız Başkumandan, Cezayir). ${ }^{2}$

Modern Uygulamalı Etik'te insan onuru kavramına değinmek yaygındır, bunun önemi ise, bu kitaptaki birçok makalede de görüldüğü gibi, ahlak teorisi açısından son derece tartışmalıdır. Sadece, insan onurunun tek başına dikkate alınması gereken bir değer olup olmadığı değil aynı zamanda herşeyden önce insan onurunun aslında ne olduğu ve bizden hangi tutumu talep ettiği de belirsizdir. Bu belirsizlikler Etik'te insan onuru kavramına seçkin bir yer ayırmanın (tıpkı Martina Herrmann' in makalesinde ifade ettiği gibi anayasal anlamda atfedilen değerin ${ }^{3}$ aksine) mantıklı olup olmayacağ ${ }_{1}$ konusunda şüphe uyandırmaktadır.

Benim makalemin amacı bunun sadece mantıklı değil, hatta aksine zorunlu olduğunu göstermektir. Çünkü çirkinliği kurbanını utanç verici duruma düşürmede, aşağılamada, onu rencide etmede yatan kimi davranışların özel etik karakterini insan onuru kavramına başvurmaksızın anlayamayız. İnsan onurunun hiçe sayıldığı durumlara konsantre olmak sadece onuru ahlak felsefesi açısından ciddeye almanın zorunluluğunu aşikar hale getirmez, bu aynı zamanda makul bir anlayış için fırsat

Stoecker, Ralf (2016) "İnsan Onuru ve Rencide Paradoksu” (Çeviren: Büşra Çakıl), Kilikya Felsefe Dergisi, (1) s. 90-108

\footnotetext{
${ }^{1}$ Alm. Stoecker R, ed. Menschenwürde - Annäherung an einen Begriff. Österreichische Ludwig-Wittgenstein-Gesellschaft: Schriftenreihe der Wittgenstein-Gesellschaft, 32. Wien: öbv \& hpt; 2003: S. 133-151.

2 Peter Koch, Reimar Oltmanns, Die Würde des Menschen, Hamburg 1977, s. 255.

3 Alman Anayasa'sının ilk maddesi "İnsan onuru dokulunmazdır" şeklindedir. Yazar burada insan onuruna Anayasa' da atfedilen değeri kastetmektedir (B.Ç.).
} 
yaratir. $^{4}$

\section{1. İnsan Onuruna Karşı Şüpheci Sav}

Ahlak felsefesindeki insan onuruna atıfta bulunmaksızın etik yapılabileceğine dair yaygın görüş ilk bakışta absürd gibi görünüyor. Sonuç itibariyle dünya üzerinde her yerde insan onurunu ihlal eden korkunç olaylar vardır: İşkence, baskı, tecavüz, köleleştirme... Sadece bir canavar bu olayların ahlaki anlamda sakıncasız olacağını iddia edebilir. Ancak bu, insan onuru kavramına şüpheci yaklaşanların savunduğu tez değildir. Onlar, bu olayları ahlak dışı kılan şeyin insan onuru ihlali olarak karakterize edilmesine karşı çıkarlar. Eleştirmenlere göre gerçekte işkence, tecavüz vesairenin ahlaki reddi için sayısız başka etik nedenler vardır. Nazi Almanya'sında yaşanan tıbbi vahşeti anlatan Wolfgang Lenzen'in aşağıdaki alıntısında bu argümantasyon için güzel bir örnek bulunmaktadır.

Nazi doktorlarının tibbi deneyler adı altında yahudiler, çingeneler ve diğer sözümona aşağı sınıf insanlara yaptığı şeye, bu kurbanların sadece insan onurunun zedelenmiş olması gibi zayıf bir savla hüküm giydirilmemeli. Aksine o zamanlar bu kurbanların çıkar ve istençlerinin kriminal bir şekilde ihlal edilmiş olduğu, onlara şiddetli acıların yaşatıldığı, sıklıkla sakat bırakıldıkları ve zaman zaman öldürüldüklerine somut bir şekilde dikkat çekilmelidir (Wolfgang Lenzen, Liebe, Leben, Tod, Stuttgart 1999, s. 193).

Lenzen burada nazi doktorlarının kurbanlarına yapılan şeyin herşeyden önce onurun hiçe sayılması alanında değil, aksine başka bir yerde yatıyor olduğu fikrini savunur, yani ruhsal ve fiziksel vahşette, haklarından mahrum bırakılmada, sağlık ve hayatlarının kaybında vs. Eğer Lenzen haklıysa bunlar bu suçların asıl utanç verici, çirkin yönleridir. Buna karşın, kendine has etik bir insan onuru kavramının savunucusu olan kişi, etik anlamda önemli olan diğer bakış açılarına işaret etmenin böylesi çirkin eylemlerdeki ahlak dişılığı ele almak için en azından her zaman yeterli

\footnotetext{
${ }^{4}$ Bu konuda Peter Schaber'in bu kitaptaki makalesiyle tamamen ayn görüşteyim. İnsan onuru tartışmasındaki en önemli hukuk felsefesi metinlerinin birisi de yine bu temel fikirden yola çıkar. Maihofer orada şunları söyler: İnsan onuru gibi birşeyin olduğu ve onun ne anlama geldiği bizim için, onun ciddi anlamda zarar gördüğü sıra dışı durumlardan başka hiçbir yerde daha açık ve net bir şekilde anlaşılır değildir. (Werner Maihofer, Die Würde des Menschen, Schriftenreihe der Niedersächsischen Landeszentrale für Politische Bildung, Hannover 1967, s. 11.)
} 
olmayacağını da göstermelidir.

Son bir kaç on yıllık süreçteki kamusal ahlak gelişimi Lenzen'in pozisyonuna öncelikle karşı bir duruş sergiliyor. İnsan onuru kavramının ikinci dünya savaşından sonra itibar kazanmasını sağlayan, onun Alman Anayasası́nda, Birleşmiş Milletler Örgütü-İnsan Hakları Evrensel Beyannamesi'nde, Birleşmiş Milletler Ana Sözleşmesi'nde ve birçok ilke beyannameleri ve kanunnamelerde yerinin sağlamlaşmasına yol açan sonuç olarak bu nazi suçlarıyd1. ${ }^{5}$ Eğer Lenzen haklı olsaydı o zaman bu gelişimin temelinde etik bir yanlış anlaşılma yatıyor olmalıydı ve içeriği net bir rencide etme kavramına da gerek olmamalıdı. Ve bu durumda bir davranışla ilintili herhangi bir saygısızlığa Lenzen' in kastettiği gibi 'zayıf bir şekilde' işaret etmiş olunmaz, aksine böylesi bir durumla iyi, hatta daha iyi başedilebilirdi. Özellikle gözle görülür rencide etmelerdeki asıl kötülük ve ahlaka aykırılık onurun hiçe sayılmasında mı yoksa bununla bağlantılı diğer başka ahlaki kusur ve suçlarda mı yatmaktadır?

Bu soruyu Nazi zamanından içinde tıbbi deneylerin olmadığı başka bir örnekle tartışmak istiyorum. Üçüncü Imparatorluk'un Resmedilmiş Tarihi'nden (alm. Illustrierte Geschichte des Dritten Reichs, B.Ç.) alınmış aşağıdaki fotoğraf, alt yazıya göre 1938 Kasım'ında Kristal Gece Katliamı (alm. Kristallnachtpogrome, B.Ç.) esnasında cam kırıkları, sivri parçalarla kaplı kaldırım taşlarını diş fırçasıyla temizlemeye zorlanan yahudi vatandaşları göstermektedir. ${ }^{6}$ Bu resmin kökeninin nereye ait olduğu söylenmiyor, ancak bu sadece 1938 sonbaharı olmak zorunda değildir, aksine belki daha öncesinde, Mart 1938'de Viyana'da, Avusturya'nın katılımının ardından gerçekleşen Hitler'in Heldenplatz konuşmasından sonraki katliamda, veya daha sonra, yani Almanya Askeri gücünün işgalinden sonra birçok Doğu Avrupa şehrinde de olmuş olabilir.

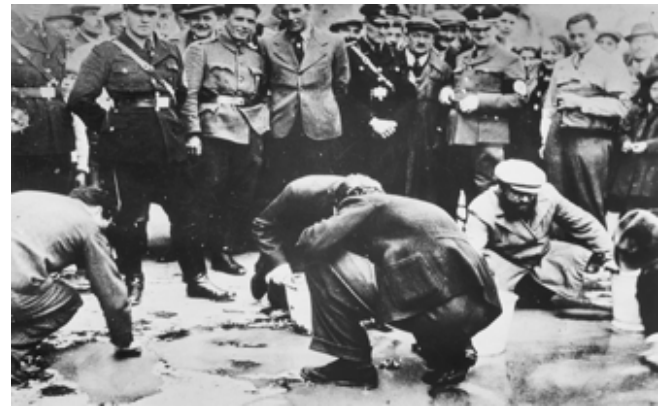

5 Bkz. Örneğin Franz Josef Wetz, Die Würde des Menschen ist antastbar, Stuttgart 1998, s. 60, ve Angela Augustin ve Markus Stepanians' in bu kitaptaki makaleleri.

6 Kurt Zentner, Illustrierte Geschichte des Dritten Reichs, München: Südwest Verlag 1965, s. 523. 
Eğer rencide etme, aşağılama, utanç verici duruma düşürme gibi davranışlar tümüyle varsa, o zaman fotoğraftaki beş adamın başına gelen de kesinlikle bunlara dahildir. Eğer rencidenin tipik bir ahlaka aykırılık olup olmadığı ve rencidenin aslında ne demek olduğu anlaşılmak istenirse o zaman bu, bu gibi örneklerden çıkarımlanmalıdır.

\section{2. Örneğin Şüpheci Bir Değerlendirmesi}

Değinildiği gibi eleştirmenlerin önerisine göre ahlaki olmama, onuru hiçe saymada değil aksine davranışın başka bir açıdan ahlaki olarak çirkin ve canice olmasındadır. Fotoğraftaki olaylar açısından bu öneri hatalı değildir. Bu adamların başına gelmiş şeyin son derece ahlak dışı olduğunu kanıtlayabilecek bir dizi etik neden vardır.

Öncelikle o zamanki işkenceler pek tabi sadece bir yerleri temizlemeye zorlamakla sınırlı değildi. Viyana'lı bir yahudi bunu aşağıdaki tasvirinde resmediyor.

Bir hemşire Kristal Gece'de şimdinin Fırtına Bölügü üyeleri (alm. SA-Leute, B.Ç.) olan yahudi dostları tarafından temizlik işine götürüldü. Diğer yahudilerle birlikte caddeleri diş fırçasıyla temizlemesi gerekiyordu. Bu bir tuzaktı ve insanlar bu arada onları izliyor onlara tükürüyor ve vuruyordu. O zamanlar bunlar gayet normaldi (Fritz Kleinmann'in raporu). ${ }^{7}$

Kurbanlara vurularak onlara bedensel acılar veriliyor, yaralanmalara sebep olunuyordu. Bu durum bu davranışı kınamak için ciddi ve cezayı ağırlaştırıcı bir sebeptir.

Aslında böyle birşey fotoğrafta farkedilmiyor, ancak yine de bu adamların başına gelmiş şeydeki ahlaka aykırılıktan hiç şüphe yoktur. Bu beş adamın tahminen içine düşmüş olduğu diğer aşağılanma durumları değil, işte bu resmedilmiş olayların kendisi bu yargıyı haklı hale getirir.

Olayın başka açıları tasvir edilmemiş ancak bunlar kolaylıkla tasavvur edilebilir. Bunlar Viyana'daki aynı şekilde benzer bir sahneye ilişkin bir diğer çağdaş raporda açıkça dile getirilmektedir.

7 Lea Rosh'dan alıntılanmıştır, Eberhard Jäckel, Der Tod ist ein Meister aus Deutschland, Hamburg 1990, s. 22. 
Kaldırımların zorla temizlenmesi, nizamiye kışlalarının zorla yıkanması vs. her ne kadar yeni rejimin diğer tutumlarına oranla bariz bir şekilde basit bir ayrıntı olsa da, yahudi halkın üzerinde çok derin bir etki yaratmıştı. Sadece böyle bir angaryaya tabi tutulmuş olmanın korkusu felç etmiyordu; böylesi rencide edici tasavvurlarla tahrik olmuş alay eden, gülünç duruma düşüren ve çığlıklar atan yahudi-olmayan kalabalığın görüntüsü bütün yahudi halkın korkunç bir şok yaşamasına neden olmuştu. Bu, yahudilerden kişisel güvenlik duygusunu ve komşularının insaniyetine duydukları inancı çalmıştı. Bu, sadece bir çılgınlar cennetinde değil aynı zamanda tam bir cehennemde yaşıyor oldukları gerçeğini de onlar için ortaya çıkarmış oldu (Leo Lauterbach'1n raporu). ${ }^{8}$

Diğer insanların bir anda insanı diş fırçasıyla kaldırımları kazımak gibi grotesk bir davranışa zorlayacak güce sahip olmaları, bunun ötesinde bu gücün normalde insanın kişisel güvencesinin garantisi olacak komşular, vatandaşlar ve devlet organları tarafından kullanılıyor olması, hayati güvensizliğin ve korkunun temel sebebini sunmaktadır. Yani işkencecilerin davranışlarını böylesi ahlak dışı kılan şey sadece fiziksel acılar ve yaralamalar değil, aynı zamanda kurbanlarını içine düşürdükleri tanımsız korkudur. Tarihin de göstermiş olduğu gibi bu korku da fazlasıyla haklı bir korkuydu.

$\mathrm{Bu}$ davranışların, kurbaların çıarlarının tersine yöneltilmiş olduğu da eklenmelidir, kibu kendiliğinden anlaşılmaktadır. Bunlar aynı zamanda genel bir pragmatik etik için de ahlaka aykırı olarak nitelenmelidir.

Şimdiye kadar davranışların kendisini etik olarak kabul edilemez kılan sonuçları hakkında konuştum. Bu davranışlarla madurların sayısız hakları ve faillerin de görevleri hiçe sayılmıştır. Pek tabi ki antisemit çetenin bu insanlara işkence etmeye hiçbir hakkı yoktu. Komşular, tanıdıklar, devlet organları kurbanların yanında olmakla görevliydi, oysa onlar bunun yerine onların temel özgürlük ve kendi kaderlerini tayin etme haklarını çiğnemede aktif bir şekilde rol aldılar. Bu eylemleri lanetlemek için bunlar da yeterli etik nedenlerdir.

Fotoğraftaki beş adama yapılan davranışın çirkinliği ahlaki açıdan defalarca tarif edildi; ahlaki reddi destekleyen birçok neden var. Bu tesbit, insan onuru kavramına değinmeksizin de bu durumla başedilebilir tezini

\footnotetext{
8 Hans Safrian' dan alıntılanmıştır, Die Eichmann-Männer, Wien, Zürich 1993, s. 31.
} 
de çürütmektedir. Diğer yandan bu adamların her şeyin ötesinde ve her şeyden önce aşağılandığ 1 neredeyse hiçbir şekilde tartışılamaz. Hem kendileri, hem failler ve hem de bunlara seyirci olanlar için hainliğin asıl can alıcı noktası da işte tam burada gizliydi. Bu, sadece bir işkence, bir özgürlük çalma, zorunlu bir önlem değildi, bu, kurbanları aşağılama ve rencide etmeydi.

\section{Utanma Duygusu}

Pek tabi ki bir insan onuru kavramı eleştirmeni kurbanların aşağılandığından şüphe duymayacaktır, ancak bunu ahlaki anlamda ehemmiyetsiz bulacaktır. $\mathrm{O}$, bunun yerine aşağılanmayla ilintili utanç duygusuna işaret edebilir. Utanma hoş olmayan acı verici bir duygudur." Utandırıcı davranış bu nedenle tıpkı korkutucu ve acı verici davranışlar gibi "acıya sebep olma ahlaki yasağına" dahildir. Bu durumda şu iddiada bulunulabilir: Yukarıda resmedilmiş davranışların aşağılayıcı karakteri kendine has bir insan onuru kavramına değinmeksizin de anlaşılabilir.

Bu tez aslında iki problemle karşı karşıyadır. Birincisi, kurbanların gerçekten utanç duygusu hissedip hissetmedikleri koşulunun ne kadar anlaşılır olduğu açık değildir. Örneğin imha kamplarından (alm. KZLager, B.Ç.) să̆ kurtulabilmiş olanların raporlarında diğer duygular (korku, bedensel tükenmişlik, açlık ve susuzluk, çaresizlik, bıkkınlık ve umut, sevgi ve düşmanlık) oldukça geniş bir şekilde tasvir edilirken, imha kamplarındaki hayatın her ne kadar aşağılayıcı olduğu anlatılmış olsa da günlük yaşam tanımlarında utanç veya aşağılanma duygularından neredeyse hiç bahsedilmemiştir. ${ }^{10}$ Eğer bu izlenim tamamen yanıltmıyorsa o halde kurbanların en ağır rencide edilme ve aşağılanma durumları her zaman bununla bağlantılı güçlü bir utanç duygusuyla yaşanmıyordur.

9 Burada utanç duygusu ile Duden'a göre ,utancı hissedebilme yeteneği' anlamına gelen utanma duygusunun (Türçe' deki ar, haya, edeb. B.Ç.) kastedilmediği açıtır.

10 Primo Levi utanç duygusunun ortadan kalkmasının bir anda gerçekleşmediğine dikkat çeker. Sürgüne yollanan insanların içine düştükleri acı verici durumun büyük bir nedeni tamamen kapalı transport vagonlarında ve yine daha sonra götürüldükleri imha kamplarında en temel ihtiyaçlarını kimse görmeden karşılayabilecek imkanlarının olmamasında yatıyordu. Levi şöyle devam ediyor: Ancak birkaç hafta içinde bu sıkıntı azaldı ve sonuç olarak tamamen ortadan kayboldu; alı̧̧malar başladı (tabi ki herkeste olmasa da!). Bu durum için merhametli bir ifade su olsa gerek: İnsanların hayvanlara dönüşmesinde bir adım ileri gidilmişti (Die Untergegangenen und die Geretteten, München, Wien, 1990, s. 113). Rencide edilmiş bir hayattan duyulan bu utanç duygusu imha kamplarındayken hissedilmemişti, oradan kurtulmuş ve hayatta kalmış bir çoğunda daha sonra dehşet verici bir şekilde ortaya çıkmıştı ve bir daha bundan kurtulamadılar (age., s. 74). 
Fotoğraftaki resmedilen durumda da şok ve hayati anlamda güvensiz hissetme, Lauterbach'ın yukardaki raporunda da bahsedildiği gibi, fotoğraftaki adamları utanç duymak ve bundan ötürü acı çekmek için fazlasıyla korkutulmuşluğa sürüklemiş olmalıdır. Pek tabi ki bu, failler için etik anlamda savunulası, affettirici bir neden olmayacaktır (bu fiziki engeli öncelemis olsalardı dahi).

Aşağılayıcı edimlerin etik anlamda önemli olan boyutunu acı verme yasağına indirgeme çabasındaki ikinci problem ise, bir edimin engellenme sebebini onun bu duyguya (utanca, B.Ç.) neden olması olarak görmeye her zaman hazır olmayışımızdır. O ana kadar namuslu bir birey olarak tanınan bir tecavüzcünün yaptığı şeyin ortaya çıkması bu kişi için son derece utanç vericidir, ancak yine de suçun aydınlatılmasına engel değildir. Utanç, adli kovuşturmadaki daha yüksek bir iyi uğruna katlanılacak zorunlu bir fenalık değildir, aksine, her ne kadar arzu edilen birşey olmasa da, etik anlamda önemsizdir.

Her iki problem de aynı yönü göstermektedir: Aşağılamaları ahlaki anlamda gözden düşüren şey sadece utanç duygusu değil, aşağılanma ediminin kendisidir. Etik, eğer başka insanları aşağılamada neyin hatalı olduğunu açıklayamıorsa eksiktir. Bunu da tahminen neredeyse hiçkimse tartışmayacaktır. Lenzen gibi insan onuru eleştirmenleri rencide kavramına illa ki bir yer ayırabilirler, ancak bu, destekçilerinin sıkça kullandığı kadar geniş olmayacaktır, öyle ki Nazi vahşetini ve işkencesini hakkıyla değerlendirebilmek için onura değinmek tahminen zayıf kalacaktır.

Yani bir insanı aşağılama ve rencide etmenin aslında ne anlama geldiği ve burada ahlaki anlamda hatalı olarak nitelenecek şeyin ne olduğu güçlü bir insan onuru kavramının hem eleştirmenleri hem de savunucuları için iyi bir sorudur.

\section{Rencide Paradoksu}

Bir insanı aşağılamak, utanç ve küçük düşürülme duygusuna sebep olmaktan farklı birşeydir. Bu, belli bir bilişsel süreçte etki sahibi olmak da değildir. Birisini, o bunu aşağılanma olarak farkedip, yorumlayıp algılamak istemeksizin aşağılayabilirsiniz. Avishai Margalit etkileyici kitabı Onur Politikası'nın (alm. Politik der Würde, B.Ç.) ilk bölümünde bunu vurgulamaktadir: 


\begin{abstract}
"Aşağılama"dan anladı̆̆ımız şey, bir kişiye kendine olan saygısını zedeleyebilecek rasyonel nedenler sunan bütün davranış şekilleri ve koşullardır. Böyle anlaşıldığı müddetçe aşağılama psikolojik olmaktan çok normatif bir kategoriyi gösterir. Bir yandan, aşağılamaların normatif anlamsal kapsamı kendini aşağılanmış hissetmek için haklı bir nedeni olan herkesin kendini gerçekten aşağılanmış hissettigini içermez. Diğer yandan kavramın psikolojik anlamından kendini aşağılanmış hisseden herkesin bu duygu için gerçekten haklı bir nedeni olduğu da çıkmamaktadır (Margalit, Politik der Würde, Frankfurt 1999, S. 23).
\end{abstract}

Aşağılanmayı fiziksel reaksiyon değil, bu reaksiyonu haklı kılan şey oluşturmaktadır. Bu arada aslında Margalit utanç duygusunun haklılığıyla ilgilenmez. Aşağılanma O'nun için, kurbana kendine duyduğu saygının zedelenmiş olduğu duygusunu verecek haklı nedeni sunan şeydir. Eğer aşağılanmanın ne demek olduğu anlaşılmak istenirse o zaman kendine saygı duyma ileneyin kastedildiği, bu duygunun zarar gördüğ ü hissine yol açacak bir nedene sahip olmanın ne anlama geldiği ve sonuç olarak bu tür zedelenmelerin ne tür bir etik öneminin olduğu ilk olarak açıklanmalıdır.

Yukarıda bahsedilen deşifre edilmiş tacizci Margalit' in tanımı için uygun bir örnek teşkil ediyor gibi görünmektedir. Bir kadına tecavüz etmiş bir kişinin şüphesiz kendisine saygı duymak için artık iyi bir nedeni kalmayacaktır. Bu açıdan Margalit gibi şunu iddia edebiliriz ki, bu kişi aşağılanmıştır, daha doğrusu kendi davranışıyla aşağılanmıştır. $O$, kendini rencide etmiştir. Polis sadece onun kendini küçük düşürmüşlüğünü ifşa etmiştir, ki bu durum onda utanç duygusu yaratmıştır. Bu nedenle tutuklamada da ahlaki anlamda hatalı olarak nitelenecek bir durum yoktur.

Ancak bu durumda son derece büyük bir problem ortaya çıkmaktadır. Şüphesiz ki bu adam sadece kendisini değil aynı zamanda kurbanını da ona tecavüz ederek aşağılamıştır. Margalit' e göre bu kurbanın da kendine duyduğu saygıyı zedeleyecek bir nedenin oluştuğu sonucu ortaya çıkmaktadır. Ancak bu, kulağa garip gelmektedir. Tecavüze uğramış, işkence görmüş bir insanın neden kendine duyduğu saygıyı azaltacak bir sebebi olmalıdır ki?

Aynı şekilde bu durum fotoğraftaki adamlar için de geçerlidir. Sadece bir vahşete kurban gitmiş olma şanssızlığını yaşadıkları için 
neden kendilerine daha az saygı duysunlar ki? Failler ve yandaşları, gizli sempatizanlar ve korkak seyirciler, işte bunların hepsinin kendilerine daha az saygı duymaları için çok güçlü sebepleri olmalıdır, savunmasız kurbanların değil.

Kısacası başkalarının yaptığı bir davranıştan ötürü kendimize duyduğumuz saygının zarar görebileceğini kabul etmek paradoks gibi görünmektedir. Margalit kendi tanımının bu soncunu görmektedir, ancak $\mathrm{O}$, bunu tanımın bir sorunu olarak değil rencide paradoksu olarak adlandırdığı, onur kavramının önemli bir niteliği olarak algılamaktadır (bkz. 7. Bölüm). Sadece bu durum çözüldüğünde onur kavramına etikte uygun bir yer tayin edilebilecektir.

\section{Paradoksun Çözümü}

Bu paradoksun çözümü için olan ilk adım özsaygı kavramını daha yakından ele almada yatmaktadır. Eğer özsaygı kişinin kendisiyle ilgili fikri olarak anlaşılırsa bu durumda paradoks ortaya çıkmaktadır. Çünkü eğer bir insan gerçekten değerli bir insansa, anlamlı işler başardıysa ancak o zaman yüksek bir özsaygıya sahip olmalıdır ve eğer düşük bir değere sahipse, canice davranmışsa, bu durumda düşük bir özsaygıya sahip olmalıdır. Ancak kişinin onurunun kırılması kişi için bir suç teşkil etmeyeceği için, böyle bir edim kişinin değerini azaltamaz, yani ona kendisini aşağıllk hissetmesi için hiçbir sebep sunmaz. Yine de onurunun kırılması alçaltıcıdır.

İşte burda paradoks yatmaktadır. Ve çözüm, özsaygı ne kişinin kendisiyle ilgili sahip olduğu fikir, ne de özdeğer duygusudur, tesbitinde yatmaktadır. Margalit bunu son derece anlaşılır kılar (bkz. s. 64 ve devamı). Bir kişi kendi becerileriyle ilgili yüksek bir inanca sahip olabilir, ancak onda eksik olan özsaygı nedeniyle dalkavukluk edip el etek öpmeye de her daim açık olabilir.

Özsayg1, özdeğer duygusuyla, yani kişinin kendisiyle ilgili sahip olduğu fikir ile aynı şey değildir. Dahası bu, bir çeşit duygudur, bir inanıştır; bu daha çok bir tavır ve düşünce şeklidir, eğilimdir. Ancak kendisine, kendi özüne özen gösteren ${ }^{11}$, dikkat eden bir kişi, özsayg1 sahibidir, tıpkı çocuğuna karşı hassas davranan bir anne gibi. Özsaygı

${ }_{11}$ Yazar burda Selbst (ing. self) kavramını kullanmaktadır. Metnin tamamında bu kavram ,öz’ olarak çevrilmiştir (B.Ç.). 
sahibi olmak demek, kişinin kendi içinde yatana, kendi özünde ne olup bittiğine önem vermesi demektir.

İnsanın özsaygısının zedelenmiş olduğunu hissetmesinin ne anlama geldiği de buna paralel olarak anlaşılması gerekir. Bu sadece, onun değer verdiği, özen gösterdiği özünün aynı şekilde zarar gördüğü anlamına gelebilir. Tıpkı çocuğuna gösterdiği özende olduğu gibi, bu durum da, yeterince özen göstermemiş olması ya da başka motifleri özsaygının önüne geçirmiş olması (kolaylık, sahip olma hırsı vs.) ya da sonuç itibariyle özüne gelecek zararı engelleyebilmek için çok zayıf veya güçsüz olması gibi sebeplere bağlanabilir. Buna bağlı olarak böyle bir zedelenmeden kimi zaman fazlasıyla kimi zaman da nispeten kişinin kendisi sorumludur.

Şayet, özün zedelenmesi esas itibariyle kişinin kendi elindedir, öyle ki bu zedeleme sadece kendisine atfedilebilir fikri kabul edilirse, bu durumda rencidelerin paradoks olduğu izlenimi ortaya çıkar. Eğer kişi bunun için her zaman gereken imkana sahip olmadığını ya da en azından kendisinden bunun beklenilmemesi gerektiğini itiraf ederse paradoks çözümlenir. (Fotoğraftaki beş adam belki de kendini kahramanca savunabilirdi, ancak yine de onlara yeterince cesur olmadıkları suçlamasında bulunulamaz.)

Rencidelerin bu yorumu fikir verici ancak yine de şimdiye kadar açıklanmamış iki kavrama dayanır: Öz ve buna zarar verme. Bu nedenle şimdiye dek yorumların sonucu her durumda koşulluydu: Eğer içimizde yatan bir öz varsa ve hasarlara karşı hassassa, o zaman aşağılama fenomenini açıklayabiliriz. Ve eğer bu öze sadece öznel olmayan bir değer atfedebilmek için sebepler de varsa, bu durumda aşağılamayı etik anlamda yargılayabilmek için bir gerekçemiz de olacaktır.

\section{6. Özsayg1}

Öz olarak niteledigim şeyin varolduğu tasavvuru bizler için hem günlük kullanımda hem de tarihi olarak çeşitli nitelemeler altında tanıdıktır. Bu fikrin kökeni örneğin Antik Yunanistan'da aristokrat şeref algisında yatmaktadır. Bizim onur kavramımızın geleneği ve yine bununla bağlantılı kişi kavramının da klasik olarak dayandırıldığı bu tasavvurlar Cicero'nun ihtarnamesi Yükümlülükler Üzerine'de (alm. Von Pflichten, B.Ç.) doruk noktasına ulaşmıştır. ${ }^{12}$ Anlaşılan o ki Cicero orada sorumluluklarını

12 Bkz. Victor Pöschel, Der Begriff der Würde im antiken Rom und später, Heidelberg 1989, ve Maximilian Forschner, "Marktpreis und Würde oder vom Adel der menschlichen Natur", içinde bulunduğu eser: H. Kössler (Hg.), Die Würde des Menschen, Erlangen 1998, s. 33-59. 
görmezden gelen oğlu Marcus'a nasıl doğru davranacağına, sosyal konumu gereği içine doğduğu verilmiş rollerine, eğilim ve yeteneklerine, kaderin muhtemel değişkenliğine ve onun bir insan olduğu gerçeğinin kendisi için seçtiği hayat planını tamamlayacağına dair detaylı tavsiyeler verir. Bütün bu rollerin onun, karşısında uygun davranması gerektiği normatif sonuçları vardır. Cicero'nun zamanında özsaygı, kişinin hem kendisinin hem de diğerlerinin bu normlara uyuyor olduğunu gözetmektir.

Modern toplumlardaki insanlar Roma'nin Patrici ${ }^{13}$ sinden daha çok sosyal role sahiptir ve hem kişinin kendi davranışı hem de kişiye başkalarının nasıl davranması gerektiği açısından sayısız normatif sonuçlar da yine bu rollerle bağlantılıdır. Bizler sürekli onur ve saygıdan bahsetmesek de (her ne kadar bu kavramlar bugün hala belli alanlarda oldukça yaygın da olsa, örneğin onurlu bir şekilde yaşlanmak ve ölmek ya da birşeyi kendimize yakıştıramamaktan bahsettiğimizde) toplumdaki yerimiz, imajimiz ve itibarımıza her zaman özen gösteririz. Her ne kadar bizler Cicero ve yurttaşlarından farklı olarak asil bir duruşa hayatımızda nadiren dominant bir yer ayırıyor olsak da, genel olarak davranış kontekslerine bağlı değişkenlik gösteren nezaket sınırlarına ve herhangi bir rezil olma durumuna meydan vermemeye özen gösteririz.

Hem davranışlarımız hem de davranış şeklimiz her an hiçbir ahlaki ağırlığı olmayan (yani iyi ile kötü insanı birbirinden ayırmayan) ancak dikkate alınmaması halinde yadırganmaya, yüz karasına dönüşmeye ve sosyal dışlanmaya neden olacak; itina gösterilmesi durumunda da kişiye ciddiyet veya cesurluk, şıklık, karizmatik veya hip olma, centilmenlik gibi toplumsal saygınlık kazandıracak sosyal kabuller, gelenekler, idealler tarafından şekillenir ve etkilenir.

Acaba bugün de bundan iki bin yıl öncesi gibi kişinin kendine olan sayg1 telkininin, onun, üstlendiğimiz rollerle bağlantılı normlara sadık davranmasında ve başkalarının da ona aynışekilde davranmasını sağlamak için uğraşmasında yattı̆̆ını varsayabilir miyiz, sorusu sorulmalıdır. Ĕ̆er böyle ise, bu normların hiçe sayılması kişiye özsaygısının zedelendiği hissi için bir neden sunmuş olacak ve yine Margalit için de bu durum rencide anlamına gelecektir. Böylece onur kırılmasının işareti nedir sorusu rencide paradoksunu da çözecek bir şekilde cevaplanmış olacaktır. Birisine fotoğraftaki pogrom kurbanlarına yapıldığı gibi davranmak komşular ve

\footnotetext{
${ }^{13}$ Antik Roma' daki seçkinler topluluğu (alm. Patrizier; ing. Patrician, B.Ç.).
} 
yurttaşlar için uygunsuz olduğu için aşağılayıcıdır.

Kuşkusuz bu cevabın iki güçlü dezavantajı vardır. Birincisi, kişinin diş fırçasıyla kaldırımları kazıma zorunluluğunu sadece iyi komşuluk geleneğine aykırı bir durum olarak tanımlamak, kötü davranışı nispetince eleştirmemek gibi görünmektedir. İkincisi, başkalarını rencide etmemek ahlaki bir görev gibi görünse de bizim çeşitli rollerle bağlantılı bazı davranış kurallarına uymamızın da bir ahlaki görev olup olmadığ 1 şüphelidir. Altmışlı yıllardaki anti otoriter tutumlar, Joschka Fischer ${ }^{14}$ in spor ayakkabıları, "Titanic"'teki modern mevki sahipleri ile hicivli ilişkiler vs. - bir rolle bağlantılı davranış beklentilerinin hiçe sayılıp çiğnendiği sayısız örnekler vardır ki bunlar bu nedenle ahlaka aykırı olarak görülmez.

Her iki itiraz da sonuç itibariyle aynı doğrultudadır. Saygısızlıklar ne doğal olarak ahlaki biçimde eleştirilecek ne de fotoğraftaki işkencecilere ithaf edilecek basit bir saygı kusurudur. Bu ancak belli bir açıdan sayg1 kusurudur, kurbanların sadece komşuluk veya yurttaşlık rollerinin değil aksine bireysel insan olmak açısından rollerinin hiçe sayılması onların davranışlarını ahlaki anlamda eleştirilesi kılar. Böylece özsaygımız kendisi için kıymetli olan öz nedir sorusuna tekrar gelmiş olmaktayım. Saygısızlığın aşağılayıcı olması onun sadece zarar görenin belli bir rolünün normatif prensiplerine karşı gelmesiyle bağlantılı değildir, bu daha çok o kişinin özünü oluşturan şeye katkıda bulunan bir rol olmalıdır.

Bunun altında yatan fikir, bizim sadece farklı rollere sahip olmamız değil aynı zamanda bireysel bir kişi rolünü de üstlenmişliğimizdir. ${ }^{15}$ Bizler hayatımızı nitelikleriyle, karakter özellikleriyle, kişisel bir geçmişiyle ve sosyal ilişkiler ağıyla işleyen bir kişinin hayatı olarak şekillendiririz. Bu roller bizim özümüzdür. Ona dikkat etmek, kabule değer bir resim vermesi için uğraşmak bizim özsaygımızın görevidir. Onu dışarıya karşı uygun bir biçimde sunmak ise onurun işidir.

İnsan onuru, sadece kişinin insan olarak oynadığı belli bir rol ile bütünleşmesi değil, aynı zamanda bir bütün olarak olduğu şey ile

14 1998-2005 Federal Almanya Dışileri Bakanı Joscha Fischer'in 80’li yıllarda devlet bakanlığ yemin törenine spor ayakkabısı ile gelmesi büyük sansasyona neden olmuş ve bu olaydan sonra ismi "spor ayakkabılı bakan" olarak anılmıştır (B.Ç.).

15 Bireysel onurunun ne olduğunu Niklas Luhman Anayasanın birinci maddesinin yorumunda detaylı bir şekilde kaleme almıştır (Grundrechte als Institution, Berlin 1965). Bireysel kimlik ve küçük düşür(ül)me arasındaki bağlantıya diğer başka sosyal bilim yazarları da yer vermiştir; örneğin Helmuth Plessner'in Grenzen der Gemeinschaft (Frankfurt/M. 2002) eserinde ve Ervin Goffman'in Stigma (Frankfurt/M. 1967) eserinde. 
uyumudur. Cicero'ya göre insanın bu bütünsel onuru, onun farklı açlardan edindiği 'parça onurlarının' bir toplamıdır. Onur, kendini her açıdan saygıdeğer bir şekilde sunmaktır. Buna karşı, birey olarak insanın modern yorumunda kişi ile onun, iyi veya kötü, üstlendiği rolleri arasında bir fark vardır. Bu veya şu kişi olmak, hem rolün sahibine karşı hem de dışarıya karşı beklentilere bürünmüş kendi kendine bir roldür. Her insan oynadığı diğer rollerin de içine entegre olduğu, kendi olduğu bir birey olma rolünü üstlenir.

$\mathrm{Bu}$, bizim özsaygımız kendisi için kıymetli olan, aranan özdür/ benliktir. Bizler içine gizlice girdiğimiz diğer rollerin de yanında bir tane kimliğe, bireysel bir şahsiyete ${ }^{16}$ sahibiz. Özsaygıya sahip olmak, sahip olunan bu şahsiyetin kişi açısından önemsiz olmaması, bunun nasıl görünüyor olduğunun bir anlamının olması, onu kolaylık ya da hirslar uğruna kurban etmemesidir. Sadece neyin şerefli neyin de şerefsizce olduğunun katı ölçüsü olmaksızın, temelde bu hala kişisel itibarın (alm. Ehre, ing. honor, B.Ç.) şu eski tasavvurudur. Bir insanın dikkate aldığ 1 öz, idiosenkratik (kişiye özel, B.Ç.) özellikler barındırabilir. Örneğin başka insanların önünde diz çökmekle (tıpkı Ortaçağ şovalyelerinin kralların önünde yaptığı gibi), cinsel tercihleri açıkça dile getirmekle (birçok önde gelen gayin yaptığı gibi), ya da kendini öldürmekle (tıpkı bazi bilançointiharlarında ${ }^{17}$ olduğu gibi) örtüşebilir. Aslolan davranışın daima başarılı bir öze olan talepten motive olmuş olması ve bunun öze zarar vermek yerine onu gerçekten desteklemesidir.

Bir insanın özüne zarar vermek tam olarak ne anlama gelmektedir sorusu kalmıştır. Bir davranışın insanın özüne zarar verebilmesi, bunun bileşenlerine sahip olan normatif çağrışımlarında yatmaktadır. Örneğin $\mathrm{x}$ olan bir kişinin y şeklinde davranması ve başkalarından da $\mathrm{z}$ şeklinde davranış görmesi beklenir. Eğer bu kişi y şeklinde davranmazsa başkaları da ona z'den başka bir şekilde davranır. Bu, kişinin x olma talebi ve hakkını zayıflatır. Böylesi bir (uyulması gerekene) riayet etmeme durumundan kaçınmak, buna engel olmak ve eğer gerçekleştiyse bunu düzeltmek, özün yeniden kusursuz olması için özsaygının bir kuralıdır (örneğin kişinin bir hakaretin öcünü alması ya da otoportresini modifiye etmesi gibi).

Ben, hepimizin çevremiz tarafından prensipte onay görmüş bireysel

\footnotetext{
16 Yazar burada persona (kişinin dışarıya karşı sergilediği şahsiyet) kelimesini kullanmaktadir (B.Ç.).

17 Bilanzsuizid: Bilincli bir şekilde planlanmış intihar (B.Ç.).
} 
bir kimliğimiz, bir özümüz, şahsiyetimiz olduğu koşulundan hareket eden bir aşağılama ve rencide kavramları anlayışını savunmaktayım. Aşağılayıcı olan, kişinin kendisinin ya da başkalarının bu kimlikle bağlantılı normatif gereklilikleri yerine getirmemesidir. Şahsiyet, kişinin aşağılandığında kaybettiği yüzüdür. Özsaygısı olan kişi kendi yüzünü korur (kendisinden ve başkalarından).

\section{7. İnsan Onuru}

Hayatta karşılaştığımız ve özsaygının aşması gereken zorluklar farklı derecelerdedir. Birçoğumuz için günlük hayatta yüzümüzü korumak neyse ki kolaydır. Bizler, Margalit'in de söylediği gibi, makul bir toplumda yaşıyoruz. Buna karşı Nazi Almanya'sında yaşamış birisi için saygıdeğer davranabilme alanı bariz bir şekilde dardı ve bunun bedeli de oldukça ağırdı. Ödön von Horvath Tanrısız Genç (alm. Jugend ohne Gott, B.Ç.) isimli hikayesinde, siyahların insan olduğu ifadesinin bir tarih öğretmeninin başına ne dertler açabileceğini tasvir eder. Ancak insan bunu başkalarına alenen savunmaksızın kendini tarih öğretmeni (ya da bir filozof) olarak görebilir mi?! Bir insanı, ya böylesi durumları sineye çekmek ya da kendi varoluşunu riske atmak arasında bir karara zorlayan toplumlar son derece aşağılayıcıdır.

Ne var ki bazen insanlar bir şekilde kabuledilebilir bir otoportreye tamamen aykırı olan şartlara çaresizce mahkum oldukları, kendi şahsiyetlerine, özlerine sarılma şanslarının hiçbir şekilde olmadığı durumlara düşerler. Sosyal birlikteliğimizin temel kabulü olan her insanın bir öze sahip olma hakkı, bu özü koruma imkanının iki temel ön koşulunun eksikliğinden ötürü yok olur: Kontrol ve dayanışma. Kimin kendi özü, bu konuda kendisinin yapabileceği birşey olmaksızın ve başkalarından yardım dileyememeksizin tehdit edilmişse onun onuru başka aşağılamalardan farklı bir şekilde tehlikeye düşer. ${ }^{18}$ Kişinin sadece olduğu ya da olmak istedigi biri olarak onuru kırılmamış, aynı zamanda kendini onurlu kılan kıymeti hiçe sayılmıştır. Eğer insanın bu temel değerliliğinin kabulü insanı insan yapan şey olarak görülürse o halde şu söylenebilir: Onun insanlığı, insan olduğu için sahip olduğu onuru, insan onuru tehdit edilmiştir.

Konunun başında Jean Amery'den yaptığımız alıntı bu gerçeği

18 İnsan onurunun bu iki temel direğini Maihofer „İnsan Onuru“ (alm. Die Würde des Menschen, B.Ç.) eserinde vurgulamaktadır. 
açıkça ifade etmektedir. Bir insanı kendisini bunun karşısında korumaya muktedir olmaksızın ya da başkalarının yardımını alamamaksızın küçük düşüren işkence, kurban için sadece aşağılayıcı ve rencide edici değildir, bu (diğer günlük aşağılanmalardan farklı olarak) insan onurunun zedelenmesidir. Kurban kendini, burada hiçbir şeyi değiştirememeksizin ve normal şartlarda ilerleyen sosyal ilişkilerden kopmuş bir şekilde, kabul edilebilir bir hayat resmine asla uymayan bir durumda bulur. Küçük düşürülme ve Cezayir' deki Fransiz şef işkencecinin girişteki ikinci alıntıda iddia ettiğine göre tam aksine güya gerçekleşmemiş olan rezil edilme, varolan sosyal durumu (işkenceciler karşısında çaresizce altta kalma halini) daha da güçlendirir.

Fransız paraşütçülerin (bir çeşit askeri birlik, B.Ç.) eline düşmenin o zamanlar ne anlama geldiğini gazeteci Henri Alleg otobiyografik raporu İşkence (alm. Die Folter, B.Ç), (München, Wien, Basel 1958)'de aktarır. Jean Paul Sartre bu kitabın önsözünde konuya dair şunları yazmıştır:

İşkencenin amacı sadece konuşturmaya, hainliğe zorlamak değildir: Kurban kendi çığlıkları ve boyun eğişiyle tıpkı insansı bir hayvan gibi kendini onursuzlaştırmalıdır. Herkesin nezdinde ve kendi nezdinde... İhaneti, kendini çiğnemeli, onu kendinden koparmalı. İskencede pes eden kişi sadece konuşmaya zorlanmak istenmez; ona bir damga vurulur: Alt sinıf insan damgası (a.g.e., s. 14).

Margalit de bu tür onur kırıcı durumlarda (insan onuru ihlallerinde) bir insanı "alt sınıf insan" yapmanın karakteristik olduğunu vurgular. Kişi son derece insana dair olan birşeyden bilincli bir şekilde men edilir, yani bireysel bir kişiliğe sahip olmaktan.

İşkence dışında insanı savunmasız, çaresizce küçük düşüren aynı karaktere sahip başka durumlar da vardır. Fotoğraftaki yahudi erkekler bunun için güzel bir örnek teşkil ederler. Kendilerinin ve başkalarının gözünde utanç verici, alçaltıcı bir durumda oldukları aşikardır. Temizlik yapmak giyinilen kıyafetler için de, diş fırçaları için de pis bir iştir. Ayrıca bu, özellikle erkekler için düşük sosyal statüsü olan bir iştir. Bunun ötesinde onlar eğilmek, dizlerinin üzerine gelmek zorunda kalmışlardır, yani bu anlamda da işkencecilerinin altında kalmış, onların ayaklarına serilmişlerdir. Ancak herşeyden önce bu bütünüyle ötekine mahkum olma hali, insanın korumasız ve savunmasızca anlamsız işler yapmak ve küfür ve hakarete katlanmak zorunda olması, kendinden emin ve kendine 
sayg1 duyan bir kişinin bütün tasavvurlarına taban tabana zıttır. Kısacası bu adamlar başlarına gelmiş şey ile onurlarından yaralanmışlardır.

\section{Onur Kırıcılığın Ahlaki Değerlendirmesine Dair}

Yukardaki bölümlerde bir insanı aşağılamanın ne demek olduğu ve kurbanın insan onurunu zedeleyen tutumların özelliğinin ne olduğunu tanımladım. Bu davranışların ahlaki değerlendirmelerine dair şu soru kalmıştır: Bir insanı aşağılamak ahlaki anlamda yasak mıdır ve eğer öyleyse sebebi nedir?

Aşağılamalara genel anlamda bakıldığında bir insanı aşağılamak her zaman ahlaki anlamda kötü değildir. Kibirli bir gösterişçinin hakkından gelmek (burnunu sürtmek) son derece takdire şayan olabilir. Bu kişi talep ettiği saygıyı hak etmemektedir. Herşeyden önce eğer bu talepler eyleyenin asıl haklarına veya dürüstlük ve adaletin temel ilkelerine ters düşüyorsa (örneğin bir kişi belli bazı imtiyazlara sahip olmayı arzu ediyorsa) bu durumda aşağılayıcı birşey yapmak etik anlamda sakıncasız olabilir ve hatta bazen bu gerekli bile olabilir.

Diğer yandan aşağılamalar genellikle acı vericidir, ki bu onları (aşağılamaları) reddeder. Ancak daha önemli olan ikinci bir bakış açısı şudur ki: eğer bir özün varlığ1 yukarda bahsettiğim gibi hayatımızda merkezi bir rol oynuyorsa, bu durumda hayatımız için onun değerini teslim etmek akla daha yakındır. Bir kimlik oluşturup bunu ayakta tutmak için uğraşmamız, sadece tesadüfi bir özellik ya da ilginç bir sosyolojik gerçek değildir, aksine son derece değerli ve korunmaya değer birşeydir. Bir insanı kişisel bir kimliği koruması için desteklemek veya ona bu konuda engel olmak yukardaki kabulden hareketle ahlaki olarak önemsiz değildir. ${ }^{19}$ Bir insanı aşağılama hakkına sahip olmak için iyi bir nedenimizin olması gerekir. Bu ilk bakışta (hemen) yapılmamalıdır.

Eğer neden insan onurunu ihlal etmek etik açıdan son derece kötüdür gibi önemli bir soru sorulursa, burada insanın özünde bilhassa korunmaya

\footnotetext{
19 Kendi özünü koruyabilmek adına kendisinden ya ancak çok küçük bir katkıda bulunmalarını bekleyebileceğimiz ya da bunu hiçbir şekilde yapamayacak insanların, örneğin bunamış olanların, etik durumuyla ilgili birşeyler söylemek için burada bu düşünce zincirini devam ettirdim. (Bkz. Kendi eserim olan "Die Würde des Embryos", İçinde bulundugu eser: D. Groß (Hg.), Zwischen Theorie und Praxis. Ethik in der Medizin in Lehre und Klinik, Würzburg 2002, S. 53-71.).
} 
değer bir nüvenin yatıyor olduğu fikri önemli bir rol oynar. ${ }^{20}$ İnsan onuru ihlalleri kurbanı sadece kendi özüne duyduğu saygıdan mahrum etmekle değil ayn zamanda kurbanın bu durumda herhangi bir özü korumasının imkânsız hale getirilmesiyle karakterize olur. Bunlar, kabuledilebilir hiçbir öz tanımı ile bağdaşmayan davranış biçimleridir. Burada ilk etik koşul doğrudan ortaya çıkar: Eğer bizim en azından (gelişigüzel olmasa da) herhangi bir bireysel sosyal kimliğe sahip olma hakkımız varsa insan onuru ihlalleri bu hakkın hiçe sayılmasıdır. Kurbanın özünü koruma hakkı bu durumda çiğnenmiştir.

Ancak son derece büyük insan onuru ihlallerinin kabul edilemezliğini açıklayan başka bir bakış açısı daha vardır. Çoğu zaman bu edimlerin etkisi onlar bittiğinde bitmez. Bu, Amery alıntısının ikinci mesajıdır: Amery der ki, işkenceyle kurbanın hayatının bir kısmı geri çevirilemez bir şekilde biter. Hayatımızın her epizotu özümüze dahil olmayı gerektirir. Bu, aşağılanmalar için de geçerlidir. Küçük çaplı aşağılanmalar belki akıldan silinip unutulabilir. Diğerleri ise örneğin intikam alınarak dengelenebilir. Ancak kişi bazen kendi öz portresini modifiye etmek, yeniden şekillendirmek zorunda kalacaktır, öyle ki tahkir kişinin biyografisinin bir parçası haline gelecektir. Özellikle tahkir insanı bir bütün olarak etkilemişse, Sartre'ın söylediği gibi, insanı alt-insan noktasına getirmişse, maruz kalınan bu hakaretin de zorunlu olarak onun bir parçası haline geldiği yeni ve daha makul bir kimlik bulmak ciddi bir yük haline gelecektir.

Fotoğraftaki adamlar için de tahminen aynı şey geçerlidir. Eğer soykırımdan kurtulabildiyseler, kendilerini nasıl tanımlayıp dışarıya nasıl sunmuş olurlarsa olsunlar, 1938`de koca bir kitlenin gözleri önünde diz çöküp caddeyi ovalayan kişiyle aynı kişi oldukları sorununu muhtemelen çözmüş olmalıdırlar. Bu durumu kendi kabuledilebilir kişiliklerinin içine yerleştirmenin bir yolunu bulmuş olmalıdırlar.

Bu en önce psikolojik bir problemdir. Travmatik deneyimlerini kendi biyografilerinin bir parçası olarak kabul etmeyi başaramayan insanlar

${ }^{20}$ Bir kimlik oluşturmanın bir değere sahip olduğu tezi Peter Baumann'in saygının bir gereksinim olduğu kabulüne, $\mathrm{O}$ burada sadece bir bireysel gereksinimden behsettiği için değil aynı zamanda sosyal topluluğun kendi üyeleri içinde karşılıklı saygıya duyduğu bir gereksinimden (ki O, bunu „insan onurunun temsili boyutu“ olarak niteler) söz ettiği için uygundur. Aynı durum Bernd Ladwigs' in buna paralel olan şu tezi için de geçerlidir: Rencide edilmeme bütün insanlar için geçerli olan bir gereksinimdir ki bu herkese eşit derecede sayg1 göstermeye itina eden bir ahlak anlayışını içerir. 
bir ömür boyunca posttravmatik stres bozukluğundan ızdırap çekerler. Ancak burada sadece psikolojik bir sorun varmış gibi görünmüyor. Eğer insanın hayat deneyimlerine bir işkence sandalyesine çığllklar içinde bağlı olmak, işkencecisinin dışkısını yemiş olmak, bir hükümlüyü ölüme göndermiş olmak gibi anılar da dahilse cazip bir öz anlayışı geliştirmek zor ve hatta bazen imkansiz bir tasavvurdur.

Eğer bu yukarda sözü edilen 'hayat hikayesine dahil etme' durumunun sadece psikolojik anlamda zor olmadığı şüphesi haklı ise, çoktan çözmüş olduğuma inandığım rencide paradoksuna son bölümde yeniden gelmiş oluyorum. Zira bu açıdan bakıldığında insanın suçsuz olduğu halde sadece başkalarının yaptığı birşeyden ötürü değerinin düşebileceği gibi birşey ortaya çıkar.

Hem sağlıklı insan idraki ve hem de etik ortak akıl (common sense) kurban olmanın bir utanç sebebi olmadığı (ve bu nedenle örneğin tecavüze uğramış kadınların aileden dışlanmalarının grotesk olduğu) konusunda ısrar ededursun, işkenceciler ve tecavüzcüler kurbanlarını küçük düşürmek ve onlara zarar vermek konusunda amaçlarını ulaşmış gibi görünüyorlar. ${ }^{21}$

Bu noktada daha fazla birşey söyleyemeyecegimi itiraf etmeliyim. Bir yandan kurban olmanın gerçekten hiçbir şekilde utanma sebebi olmadığının gün gibi açı olduğuna inanıyorum. Diğer yandan ağır insan onuru ihlallerinin sadece bedensel ve ruhsal yaralar birakmayı aynı zamanda bir bütün olarak insanın hayatını, özünü, şahsiyetini ilelebet zedeleyebileceğinden son derece eminim; öyle ki bir insanın böylesi muamelelerle yerle bir edildiği bazen gerçekten doğrudur - her ne kadar daha sonra psikolojik hasta olmayıp aksine belki Amery, Levy, Alleg ve daha birçokları gibi insanlık suçlarına karşı savaş ile geçmiş etkileyici bir hayat sürmüş olsa bile.

21 Pavel Kohout bu inancı şu şekilde formüle etmiştir: Ancak nasıl ki cellatlar bayrağı başkasına teslim edercesine, birbirlerine acı ve ölüm reçetelerini devrediyorlarsa bizler de diğerleri için en azından bir hor görme zinciri oluşturmalıyız. Böylece insanlık onurunu kaybetmiş olanın, kurbanları değil, kendileri olduğundan hiçbir zaman şüphe duyamayacaklardır. (P. Koch, R. Oltmanns, Die Würde des Menschen, op. Cit., s.269.) Ben burda suçluların kendilerini kendi davranışlarıyla nasıl asağıladıklarına değinmedim. Ancak Kohout kurbanların özsaygılarına başkalarının da saygı duyması gerektiği için onurlarını kaybetmedikleri konusunda kesinlikle haklıdır. Burdaki sorun sadece aşağılayıcı davranışın kişinin kendini oluşturma ve kanıtlamasını zor hale getirmesinde yatmaktadır. 


\section{Sonuç}

İnsan onurumuz, insan olarak hususi, kişisel bir role, bir öze olan hakkımızda yatmaktadır. Birisini böyle bir özü oluşturmak veya korumak konusunda engellemek insan onuruna aykırı davranışların belireyici niteliğidir. Kim tutunabileceği bir kimliğe sahip olma imkanını yok edecek derecede aşağılanmış ise onun onuru hiçe sayılmıştır. $O$, Margalit' in ifade ettiği gibi "insanlık ailesi"nden ihraç edilmiştir (Politik der Würde, s. 135, 166.). Burda onun bir insan olarak görülmediği değil, artık bir kişi (Person) olmadığı sonucunu doğuracak bir şekilde davranıldığı kastedilir ki kişi, bir şahsiyeti, bir özü olandır.

Bana, insan onuru ihlallerinde aslolan burda yatıor gibi gelmektedir. Bizim olduğumuz kişi sadece bize bağlı değildir, o aynı zamanda karşılaştığımız durumlara ve özellikle bize nasıl davranıldığına bağlıdır. Başımıza gelen herşey biyografimizin bir parçasıdır ve böylece öz-portremize, şahsiyetimize dahil etmemiz gereken şeylerdir. Genel olarak yaşadığımız birçok şeyde bu bir sorun teşkil etmez, bu nedenle kendimizden doğru olduğuna inandığımız kişiyi meydana getirmemiz için büyük bir hareket alanımız vardır. Ancak olmak istediğimiz kişiye çok zor yakışır veya hiçbir şekilde uymayacak durumlarla da karşılaşabiliriz. Kim bunlara boyun eğmek zorunda kalırsa kendisini o andan itibaren yeni ve aslında olmak istemediği bir kişi olarak görmeye ve bu şekilde davranmaya zorlanmıştır. İnsancıl kişilerin bir anlamda tözüne dokunan bu hasar ne insan onuru ihlalleriyle direk bağlantılı (insanlara verilen acılar veya hiçe sayılan haklar gibi) diğer suçlara indirgenebilir, ne de hafife alınası düzeyde basittir. Bu daha çok, bireysel varlıklardan oluşan sosyal bir topluluğun üyesi olarak insanın nüvesini ilgilendirir. ${ }^{22}$

Çeviren: Büşra Çakıl, Potsdam Üniversitesi, Almanya

22 Jens Kulenkampff'a fikirleri, önerileri ve eleştirilerinden dolayı çok tesekkür etmek isterim. Onunla olan fikir alışverişimiz olmasaydı benim için birçok şey daha karmaşık olacak ve belirsiz kalacaktı. 